\title{
Potential Flood and Debris Hazards at Katherine Landing and Telephone Cove, Lake Mead National Recreation Area, Mohave County, Arizona
}

By Otto Moosburner

U.S. GEOLOGICAL SURVEY

Water-Resources Investigations Report 87-4081

Prepared in cooperation with the

NATIONAL PARK SERVICE

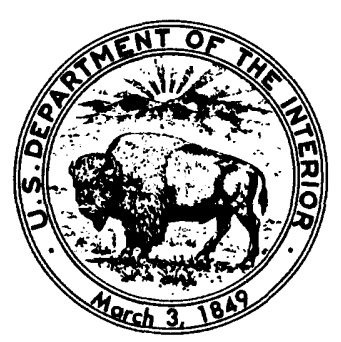

Carson City, Nevada 1988 
DEPARTMENT OF THE INTERIOR

DONALD PAUL HODEL, Secretary

\section{U.S. GEOLOGICAL SURVEY}

Dallas L. Peck, Director

For additional information write to:

\section{U.S. Geological Survey}

Room 227, Federal Building

705 North Plaza Street

Carson City, NV 89701
Copies of this report may be purchased from:

U.S. Geological Survey Books and Open-File Reports Section Federal Center

Box 25425

Denver, CO 80225 
ABSTRACT - 1

INTRODUCTION - 1

HYDROLOGIC SETTING - 2

POTENTIAL FLOOD AND DEBRIS HAZARDS - 7

Basic concepts - 7

Katherine Landing - 14

Telephone Cove - 15

DISCUSSION OF STUDY RESULTS -

REFERENCES CITED -

ILLUSTRATIONS AND TABLE

Figure 1. Index maps showing location of study area - 3

2. Vertical aerial photograph of Katherine Landing and vicinity -

3. Map showing location of sites for which peak-flow estimates have been made

4. Map showing location of cross sections in figures 5-7 --- 10

5-7. Cross sections showing floodflow characteristics:

5. South Katherine Landing Wash 11

6. North Katherine Landing Wash 12

7. South Telephone Cove Wash

Table 1. Peak-discharge estimates 5 
"Inch-pound" units of measure used in this report may be converted to metric (International System) units by using the following factors:

\begin{tabular}{lcl}
\multicolumn{1}{c}{ Multiply } & By & \multicolumn{1}{c}{ To obtain } \\
Acre-feet (acre-ft) & 0.001233 & Cubic hectometers $\left(\mathrm{hm}^{3}\right)$ \\
Cubic feet per second & & \\
$\quad(\mathrm{ft} / \mathrm{s})$ & 28.32 & Liters per second (L/s) \\
Feet (ft) & 0.3048 & Meters (m) \\
Feet per second (ft/s) & 0.3048 & Meters per second (m/s) \\
Inches (in.) & 25.40 & Millimeters (mm) \\
Miles (mi) & 1.609 & Kilometers (km) \\
Square miles $\left(\mathrm{mi}^{2}\right)$ & 2.590 & Square kilometers $\left(\mathrm{km}^{2}\right)$
\end{tabular}

For temperature, degrees Fahrenheit $\left({ }^{\circ} \mathrm{F}\right)$ may be converted to degrees Celsius $\left({ }^{\circ} \mathrm{C}\right)$ by using the formula ${ }^{\circ} \mathrm{C}=0.556\left({ }^{\circ} \mathrm{F}-32\right)$.

\section{ALTITUDE DATUM}

In this report, "sea level" refers to the National Geodetic Vertical Datum of 1929 (NGVD of 1929), which is derived from a general adjustment of the first-order leveling networks of both the United States and Canada. 


\begin{abstract}
POTENTIAL FLOOD AND DEBRIS HAZARDS AT
KATHERINE LANDING AND TELEPHONE COVE,

LAKE MEAD NATIONAL RECREATION AREA, MOHAVE COUNTY, ARIZONA
\end{abstract}

By Otto Moosburner

ABSTRACT

Katherine Landing is a recreation site on the east shore of Lake Mohave, an impoundment on the Colorado River southeast of Las Vegas, Nevada. With proper inspection and maintenance, the present (1979) channel and diking system at Katherine Landing is judged adequate to confine and restrain floods up to and including the 100-year flood. In contrast, the 500-year flood probably would not be confined by some parts of the diking system.

The Telephone Cove area, traversed by North and South Telephone Cove Washes, is hazardous for all floods, especially for the 100-year and more severe floods.

Determinations of peak discharge are based on streamflow regression analyses, and channel capacities are based on field surveys of channel-flow capacities.

The extreme flood--a flood meteorologically and hydrologically possible but so rare as to preclude a frequency estimate--could cause great damage and possible loss of life at both the Katherine Landing and the Telephone Cove sites. The present dikes would be topped or breached by extreme flooding.

\title{
INTRODUCTION
}

In 1979 the National Park Service asked the U.S. Geological Survey to study the flood-hazard potential of the Katherine Landing and Telephone Cove sites in the Lake Mead National Recreation Area. The National Park Service has instituted a program to assess flood-related hazards at all recreation sites in the Lake Mead Recreation Area. This information is expected to provide a basis for making safety-related modifications at existing recreation sites, or, as a minimum, to determine flood hazards associated with present operations. 
The purpose of this report is to present estimates of the severity of floods and channel flow capacities at Katherine Landing and Telephone Cove. In addition, the report includes the presentation of estimated flow velocities, estimated flow depths, and a cursory appraisal of flood-protection adequacy.

Katherine Landing is a developed recreation site on the Arizona side of Lake Mohave, about 2 miles north of Davis Dam and 70 miles southeast of Las Vegas, Nev. (figure 1). At the site, a National Park Service-licensed concessionaire operates permanent facilities, such as docks, a restaurant, a motel, and a mobile home area for semipermanent residents. Camping and picnicking facilities also are provided for the motor traveler (figure 2). Telephone Cove is an undeveloped site about half a mile north of Katherine Landing. The cove is extensively used, although facilities of any kind are lacking. Road access to both sites is from the west by U.S. Highway 95 and Nevada Highway 163, and from the east by U.S. Highway 93 and Arizona Highway 68 (figure 1).

\section{HYDROLOGIC SETTING}

Significant fluctuations in the water level of Lake Mohave are caused by releases at Davis and Hoover Dams (figure 1). A11 development at Katherine Landing is above the maximum possible controlled elevation at Davis Dam, and all floods that might occur therefore result from local streamflow.

The climate at the study sites is arid. At Davis Dam, the mean annual precipitation, based on more than 20 years of data collection, is about 4 inches. Measured mean annual precipitation at Willow Beach, about 45 miles north, and at Needles, Calif., about 25 miles south, is also about 4 inches. Maximum air temperatures at all three sites have exceeded $120^{\circ} \mathrm{F}$.

Al1 stream channels (locally termed "washes") in the vicinity of Katherine Landing and Telephone Cove are dry except during or immediately after heavy precipitation. The period from June to October is the most likely period of streamflow. Convective thunderstorm cells that are isolated and small in area, or are imbedded in large-scale tropical storm systems, may cause short-term flooding. Although the magnitudes of flows have not been monitored at either recreation area, flood damage has not been significant since the Katherine Landing recreation site was established and since Telephone Cove has received substantial use. The fact that the sites have not been flooded in recent years, however, does not indicate that a major flood event could not occur. 


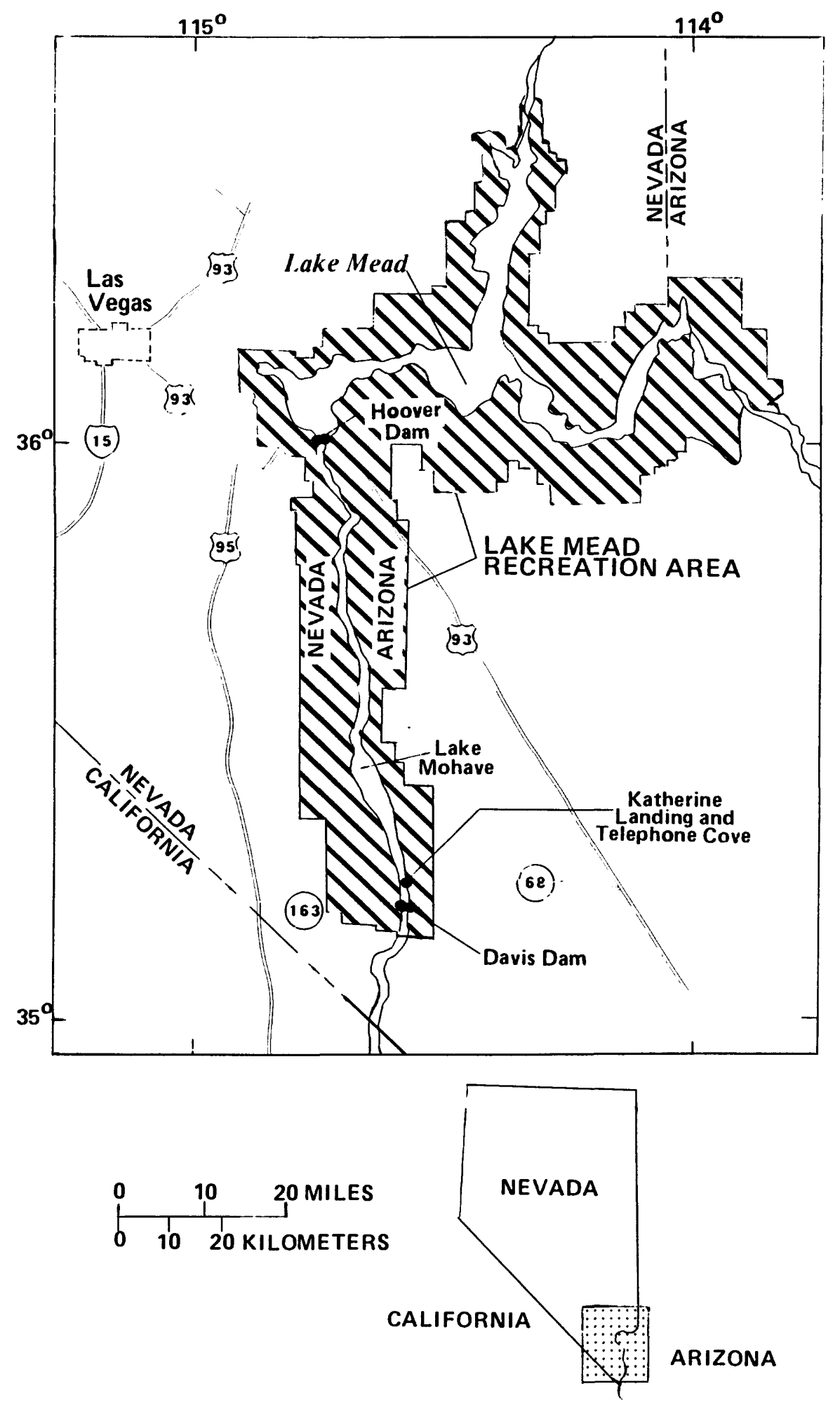

FIGURE 1.--Location of study area. 


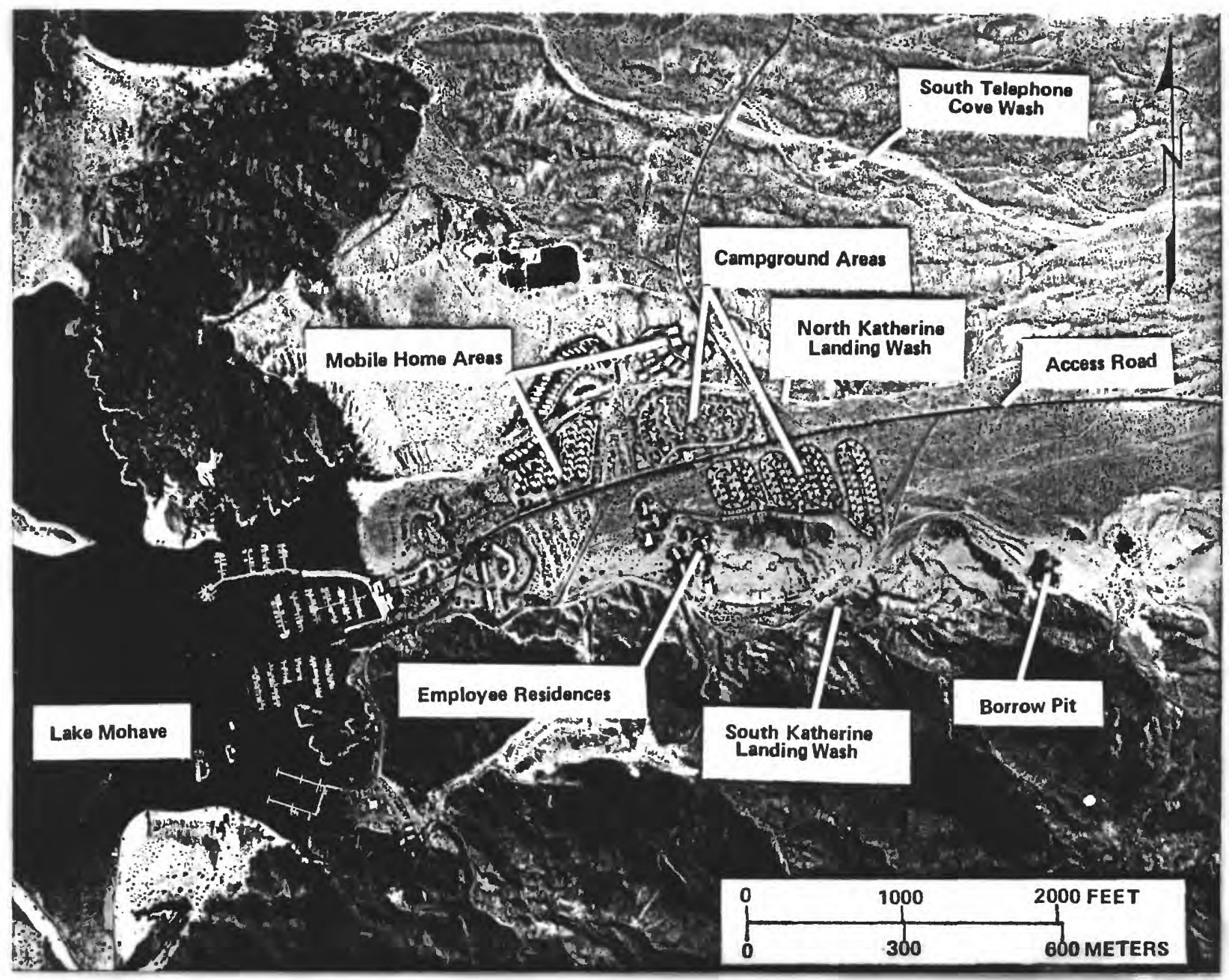

FIGURE 2.--Katherine Landing and vicinity, September 4, 1977. Photograph by Cooper Aerial Surveys.

Significant planning and construction have gone into flood protection and amelioration at Katherine Landing. The site is on unconsolidated alluvium that slopes about 4 percent westward toward Lake Mohave. Consolidated rocks form the steep southern side of the roughly 1/4-mile-wide valley. The north side of Katherine Landing is separated from Telephone Cove by 100-foot high or less intervening topography. To lessen the flood hazards at the Landing, dikes were built on the north, south, and east sides of the recreation site so that flood flows would generally bypass developed areas. (Formerly, the flood flows presumably passed through what is now the recreation site.)

The severity of flood and debris hazards is dependent on the magnitude of the flood flows and the adequacy and integrity of the diversion works. Telephone Cove is an undeveloped recreation site immediately north of Katherine Landing. Flood-protection measures are nonexistent at both the North and South Telephone Cove washes. Descriptions of the diversion and diking works are presented in a following section of the report.

Because none of the washes are named on any available maps, descriptive names have been assigned herein (table 1 and figure 3 ). 
TABLE 1.--Peak-discharge estimates

[--, not applicable]

\begin{tabular}{|c|c|c|c|c|c|c|c|c|c|}
\hline & \multirow{2}{*}{$\begin{array}{l}\text { Site number } \\
\text { and name } \\
\text { (figure } 3 \text { ) }\end{array}$} & \multirow{2}{*}{$\begin{array}{l}\text { Flow from } \\
\text { borrow pit } \\
\text { and its } \\
\text { tributaries }\end{array}$} & \multirow{2}{*}{$\begin{array}{l}\text { Drainage } \\
\text { area } \\
\text { (square } \\
\text { miles) }\end{array}$} & \multicolumn{6}{|c|}{$\begin{array}{c}\text { Peak discharge, in cublc feet per } \\
\text { second, for indicated recurrence } \\
\text { interval (years) }\end{array}$} \\
\hline & & & & 10 & 25 & 50 & 100 & 500 & $\begin{array}{l}\text { Extreme } \\
\text { flood }\end{array}$ \\
\hline 1. & Houseboat Wash & - & 0.16 & 45 & 95 & 150 & 240 & 570 & 1,600 \\
\hline 2. & $\begin{array}{l}\text { South Katherine } \\
\text { Landing Wash at } \\
\text { outlet from } \\
\text { borrow pit }\end{array}$ & Yes & .70 & 100 & 210 & 330 & 490 & 1,100 & 6,500 \\
\hline 3. & $\begin{array}{l}\text { South Katherine } \\
\text { Landing Wash at } \\
\text { Ranger residences }\end{array}$ & No & .26 & 60 & 120 & 200 & 300 & 710 & 3,000 \\
\hline \multirow[t]{3}{*}{4.} & $\begin{array}{l}\text { South Katherine } \\
\text { Landing Wash } \\
\text { at mouth: }\end{array}$ & & & & & & & & \\
\hline & (A) & No & .58 & 90 & 190 & 300 & 450 & 1,000 & 5,500 \\
\hline & (B) & Yes & 1.28 & 150 & 290 & 450 & 660 & 1,500 & 12,000 \\
\hline 5. & $\begin{array}{l}\text { North Katherine } \\
\text { Landing Wash }\end{array}$ & - & .19 & 50 & 100 & 170 & 260 & 610 & 1,800 \\
\hline 6. & $\begin{array}{l}\text { South Telephone } \\
\text { Cove Wash at } \\
\text { diversion dike }\end{array}$ & - & 1.29 & 150 & 290 & 450 & 660 & 1,500 & 12,000 \\
\hline 7. & $\begin{array}{l}\text { South Telephone } \\
\text { Cove Wash at mouth }\end{array}$ & - & 1.80 & 180 & 340 & 530 & 780 & 1,700 & 15,000 \\
\hline 8. & $\begin{array}{l}\text { North Telephone } \\
\text { Cove Wash at mouth }\end{array}$ & - & 9.60 & 460 & 940 & 1,200 & 1,800 & 3,600 & 50,000 \\
\hline
\end{tabular}




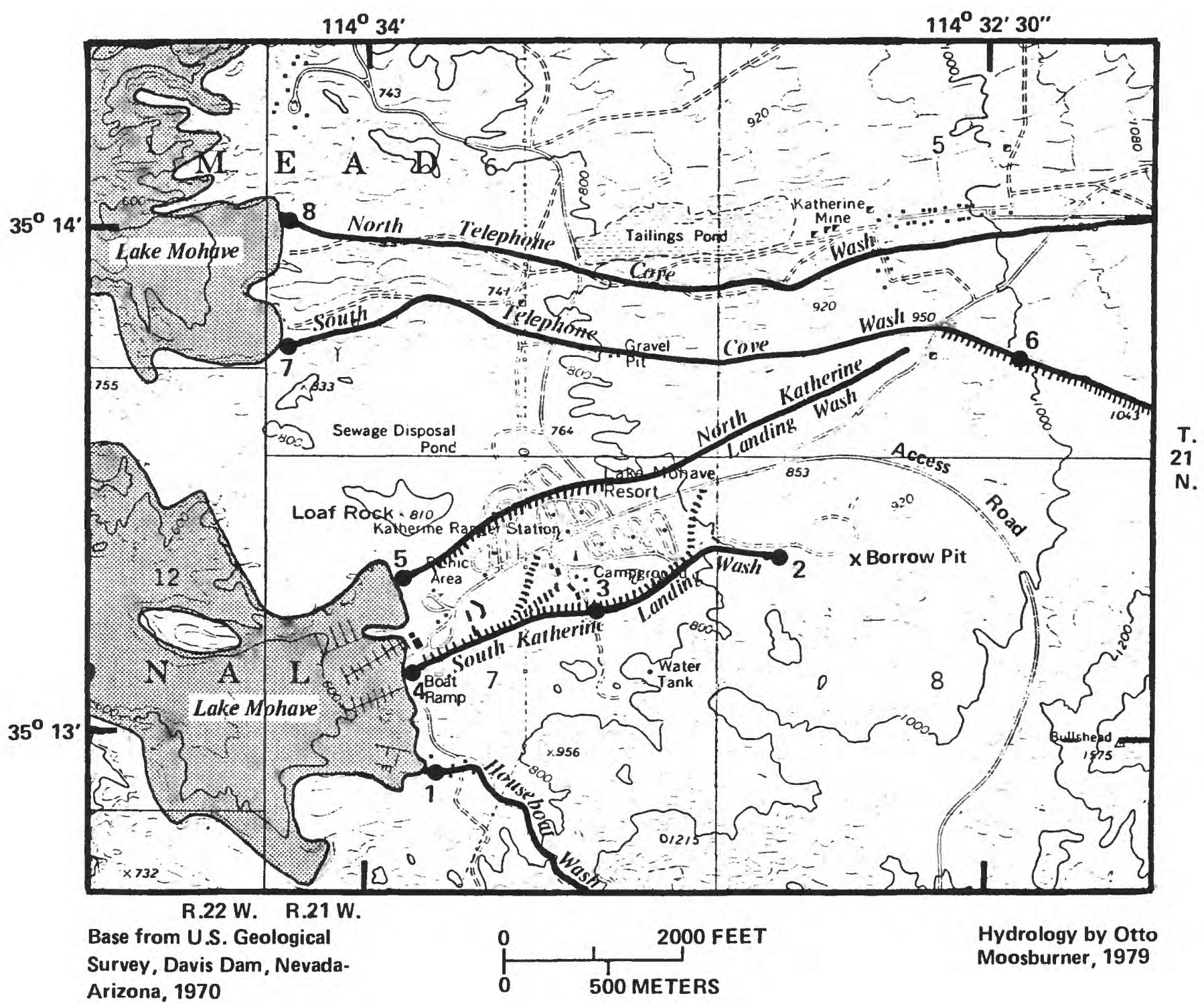

EXPLANATION Site of peak-flow estimate,
with site number (table 1)

FIGURE 3.--Location of sites for which peak-flow estimates have been made. 


\section{POTENTIAL FLOOD AND DEBRIS HAZARDS}

\section{Basic Concepts}

As considered in this study, potential flood and debris hazards are defined by several characteristics of streamflow: flow velocity, flow depth, areal extent of flood inundation, and the amount and character of debris likely to be mobilized by the flows. Generally, the greater the flow velocities and flow depths, the greater are the flood hazards. However, even shallow flows at high velocities can be hazardous. A person would have difficulty maintaining his or her footing in a flow that is 2 feet deep and moving 5 feet per second. If flow velocities and depths become large enough, automobiles and mobile homes would be transported by floodflows and could be upended or destroyed. Similarly, floods that inundate large areas pose greater hazards than floods of more limited areal extent. In addition, debris moving with the water increases the hazard. Among the chief hazards caused by debris loads are the obstruction and modification of floodflows, abrasion and impact by the moving debris, and burial by debris deposition.

To appraise the flood potential at a site, the magnitude and frequency of flooding and the capacity of the stream channel must be determined. Flow magnitude is expressed as discharge, or flow volume, per unit of time. The term recurrence interval is used to indicate the frequency of flooding and is defined as the average interval of time within which a flood of a given magnitude is exceeded. A flood with a recurrence interval of 100 years is of a magnitude that is exceeded once in 100 years, on the long-term average. The concept implies no regularity in the recurrence of a given flood magnitude, however. Two so-called 100-year floods could occur in consecutive years, or even within the same year.

Flood frequency may also be expressed in terms of probability. The probability of occurrence of a flood exceeding the 100-year flood in any given year is 1 in 100 , or 0.01 . Simllarly, the probability of occurrence of a flood exceeding the 50-year flood in any given year is 1 in 50 , or 0.02 .

Estimates of peak discharge for floods of a given frequency are usually made by one or more of the following methods:

1. A record of measured flood-peak discharges at the site in question.

2. Empirical relations between magnitude and frequency of flooding and measurable basin parameters.

3. Regional flood-frequency relations.

4. Rainfall-runoff models. 
A long record of measured flood-peak discharges (method 1) is desirable in estimating the flood-frequency relation at a site on a wash or stream. The number of sites, however, at which records of peak discharges are collected is, of course, relatively small. None of the washes draining to Katherine Landing or Telephone Cove has been monitored for flood magnitude. Hence, this method could not be applied.

Method 2 refers to the numerous procedures that are in common use for estimating peak discharges: Those of the Soil Conservation Service, Chow (1962), the Bureau of Public Roads (Potter, 1961), and the Rational method are a few examples. Shortcomings of these methods are significant. Typically, the data on which they are based are limited, were not collected in the arid west, and are not accompanied by calibration or error evaluations. Accordingly, method 2 was not attempted.

Regional flood-frequency relations are statistical but are based on collected peak-discharge data at many measurement sites in a relatively small area. The methods can be applied at study sites where basin and climatic characteristics are within the range of those characteristics determined at measured sites. This technique was the one chosen for this study.

Rainfall-runoff models commonly route input precipitation (with regard to both magnitude and spatial distribution) through the watershed to estimate peak-discharge magnitudes. Reliabilities are greatly increased if the input-output values can be calibrated. Because calibrated values are not available for the study area, this method was not used.

The magnitude and frequency of floods for the different washes at the study sites were estimated (table 1 and figure 3 ) using the results of regional flood-frequency regression studies made for streams in desert areas of northwest Arizona (Roeske, 1978). This technique was chosen because of its geographical applicability and because insufficient data exist to apply the other methods. The standard errors of estimate for the 10-year to 500-year flood-frequency discharges range from 80 to 105 percent (Roeske, 1978, page 5). The "errors" in the term "standard errors of estimate" do not indicate mistakes, but reflect the uncertainty inherent in the calculated discharge magnitudes. All the other previously mentioned techniques also exhibit standard errors of estimate; they may be larger than those determined in the regression study but are commonly impossible to specify. A flood-frequency regression study made in California (Waananen and Crippen, 1977) is based on data collected west of the Colorado River and south of Nevada. Using that technique, flood-frequency magnitudes for the washes at Katherine Landing and Telephone Cove were determined to range froin about 20 to 300 percent greater for the 100-year flood than those calculated by Roeske (1978). The actual flood-frequency discharges for the study area could be higher or lower than those developed in the present study, but the calculated values are considered to be the best estimates available. 
An upper limit of extreme flood severity for the washes was estimated by using a relation based on maximum observed (measured) floods in flood region 16 (Crippen and Bue, 1977, page 15). Region 16 encompasses southeastern California and most of Arizona and Nevada. Flood magnitudes nearly as large as those computed from the relation are possible. For example, on September 14, 1974, Eldorado Canyon--about 30 miles north of Katherine Landing--experienced a flood that was calculated to be about 70 percent of the extreme flood; and on August 19, 1971, a flood on Bronco Creekabout 60 miles southeast of Katherine Landing--was calculated to be about 75 percent of the extreme flood. Undoubtedly, many floods that approach or exceed the estimated extreme flood are not documented. The estimated extreme flood magnitudes at the study sites are shown in table 1.

Channel characteristics that influence the flow-carrying capacity of several washes were measured as part of the field survey. Standard surveying techniques and instruments were used. The conditions of the channel and cross-sections were documented with stereoscopic photos. The characteristics measured were the cross-sectional area and channel slope. The channel characteristics and the appropriate peak discharges were used to estimate the mean velocity and maximum depth for the various recurrenceinterval floods. Because of the steep alluvial channels, critical depth and critical velocity were assumed for all peak discharges.

Figure 4 shows the location of cross sections where measurements and estimates were made. Figures 5-7 show the cross sections themselves for South and North Katherine Landing Washes and South Telephone Cove Wash, respectively. Figures 5-7 also list the estimated mean velocities and maximum depths for the various recurrence-interval floods.

Floods in arid areas commonly mobilize and transport large amounts of debris. By weight, the debris is composed mainly of inorganic sedimentary materials that can range in particle size from clay to boulders. Organic and man-related debris, although generally minor weight components of the total debris load, can nonetheless constitute a large part of the total flood-debris volume, especially in developed basins. The organic and manrelated components can have pronounced effects on the nature of flooding because they are generally more buoyant than the inorganic load. This buoyancy promotes congestive jamming and obstructions, and thereby hinders the efficient transport of the floodflows.

Sedimentary debris also tends to obstruct and modify the flood flows during transit, particularly when large quantities of the debris are incorporated into the leading edge of the initial flood wave. The author has observed that debris at the leading edge of the flow acts as a moving dam that influences the depth of floodwater behind the front, and the great momentum and abrasive character of the debris poses a serious hazard to anything in its path. This moving-dam effect also is capable of diverting the flood path of the trailing water if the flood channel is poorly incised and the surrounding terrain has a low topographic relief. 


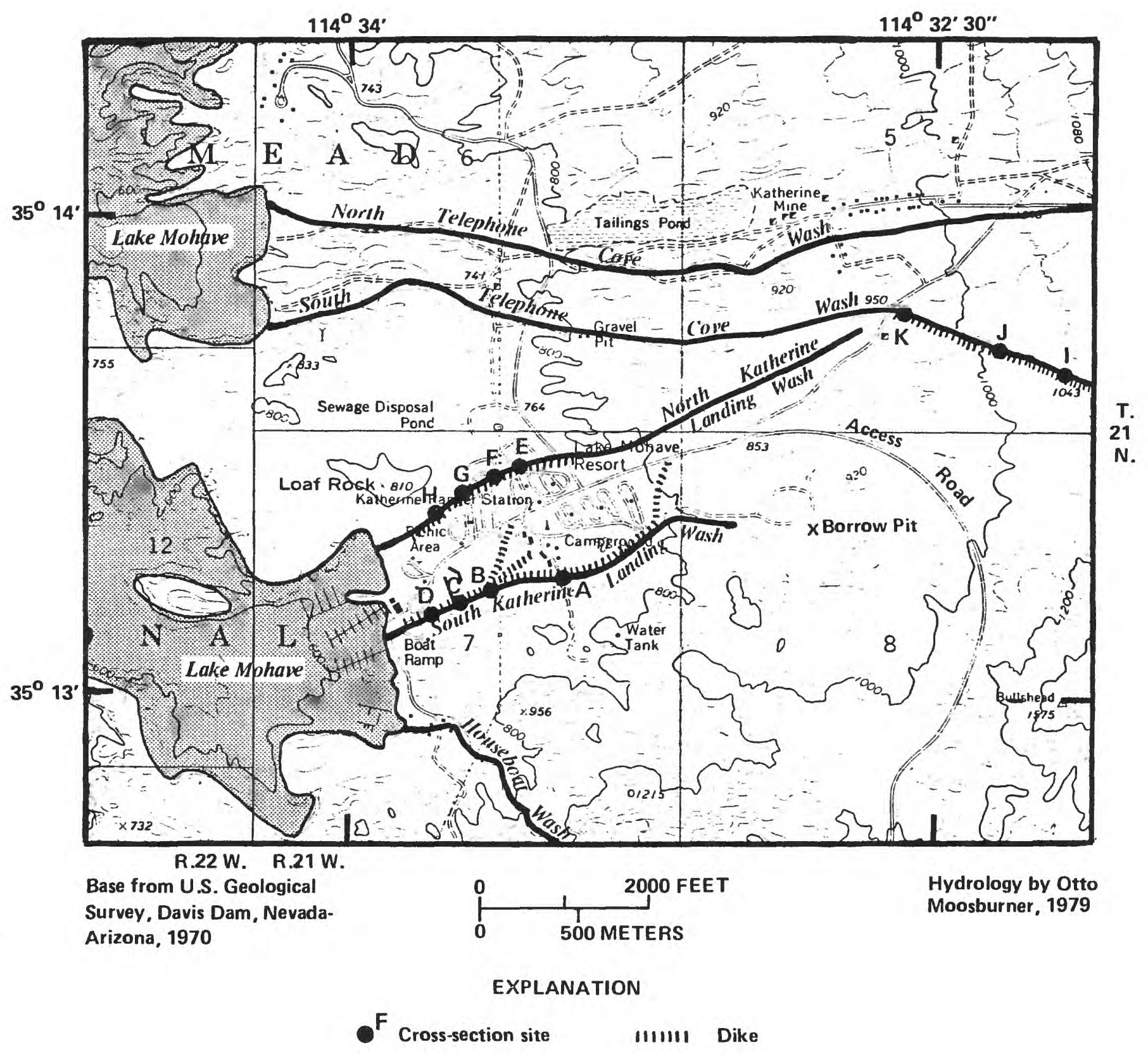

FIGURE 4.--Location of cross sections in figures 5-7. 
SECTION A

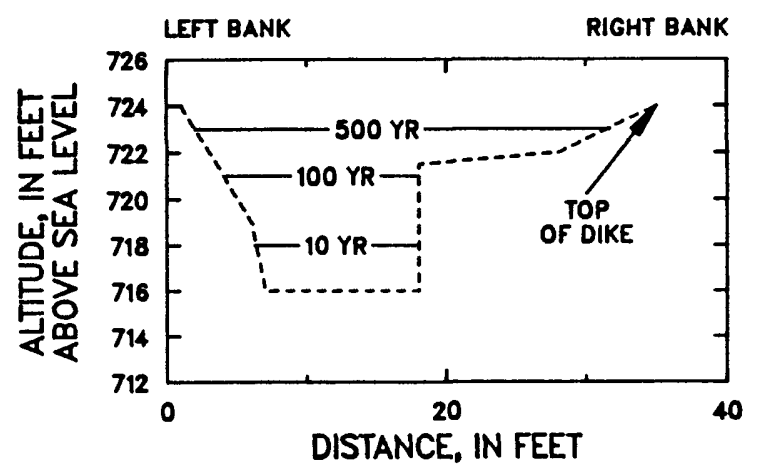

SECTION C

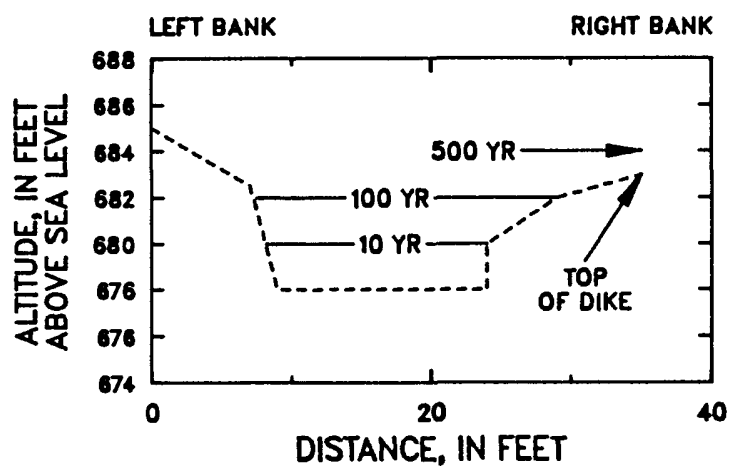

SECTION B
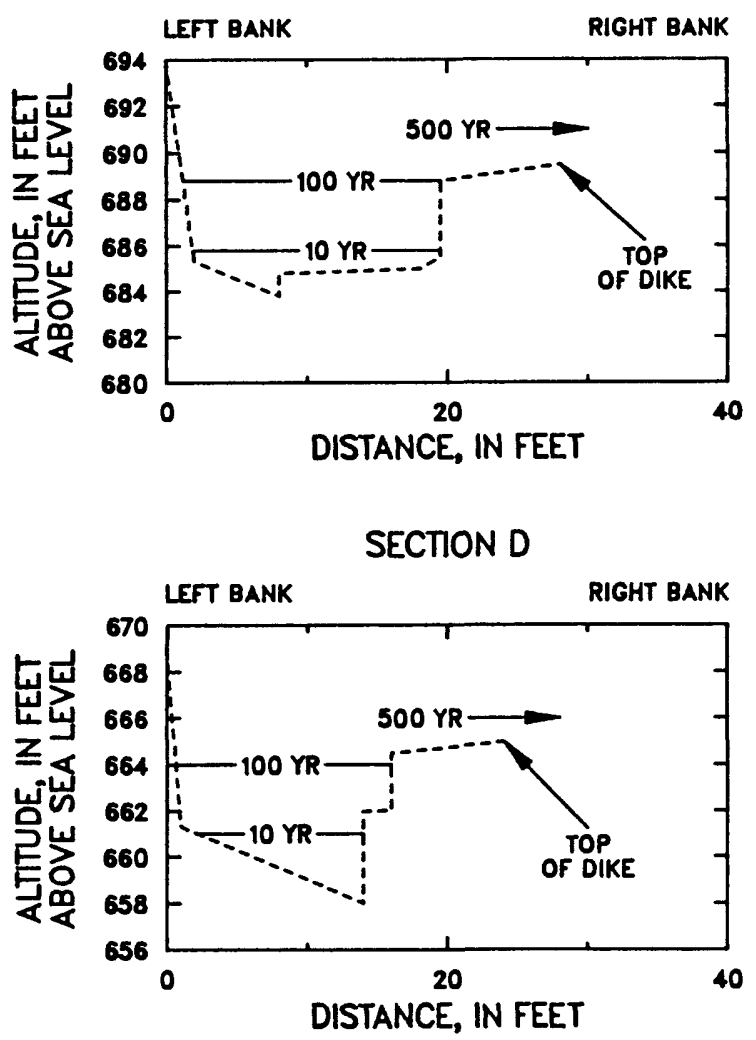

\begin{tabular}{|c|c|c|c|c|c|c|c|c|}
\hline \multirow[b]{2}{*}{$\begin{array}{l}\text { Recurrence } \\
\text { interval } \\
\text { of peak } \\
\text { discharge } \\
\text { (years) }\end{array}$} & \multicolumn{2}{|c|}{ section $A$} & \multicolumn{2}{|c|}{ section $B$} & \multicolumn{2}{|c|}{ section C } & \multicolumn{2}{|c|}{ section $D$} \\
\hline & $\begin{array}{l}\text { Mean } \\
\text { velocity } \\
\text { (feet } \\
\text { per } \\
\text { second) }\end{array}$ & $\begin{array}{l}\text { Maximum } \\
\text { depth } \\
\text { (feet) }\end{array}$ & $\begin{array}{l}\text { Mean } \\
\text { velocity } \\
\text { (feet } \\
\text { per } \\
\text { second) }\end{array}$ & $\begin{array}{l}\text { Maximum } \\
\text { depth } \\
\text { (feet) }\end{array}$ & $\begin{array}{l}\text { Mean } \\
\text { velocity } \\
\text { (feet } \\
\text { per } \\
\text { second) }\end{array}$ & $\begin{array}{c}\text { Maxinum } \\
\text { depth } \\
\text { (feet) }\end{array}$ & $\begin{array}{l}\text { Mean } \\
\text { velocity } \\
\text { (feet } \\
\text { per } \\
\text { second) }\end{array}$ & $\begin{array}{l}\text { Maximun } \\
\text { depth } \\
\text { (feet) }\end{array}$ \\
\hline 10 & 7 & 2 & 6 & 2 & 7 & 2 & 7 & 3 \\
\hline 25 & 9 & 3 & 8 & 3 & 8 & 2 & 8 & 4 \\
\hline 50 & 10 & 4 & 9 & 4 & 9 & 3 & 10 & 5 \\
\hline 100 & 11 & 5 & 10 & 5 & 10 & $4 *$ & 11 & 6 \\
\hline $\begin{array}{c}500 \\
\text { extreme }\end{array}$ & $\begin{array}{r}14 \\
>14\end{array}$ & $>7$ & $\begin{array}{l}>10 \\
>10\end{array}$ & $\begin{array}{l}>6 \\
>6\end{array}$ & $\begin{array}{l}>10 \\
>10\end{array}$ & $\begin{array}{l}>4^{\star} \\
>4\end{array}$ & $\begin{array}{l}>11 \\
>11\end{array}$ & $\begin{array}{l}>6 \\
>6\end{array}$ \\
\hline
\end{tabular}

FIGURE 5.--Floodflow characteristics, South Katherine Landing Wash. 
SECTION E

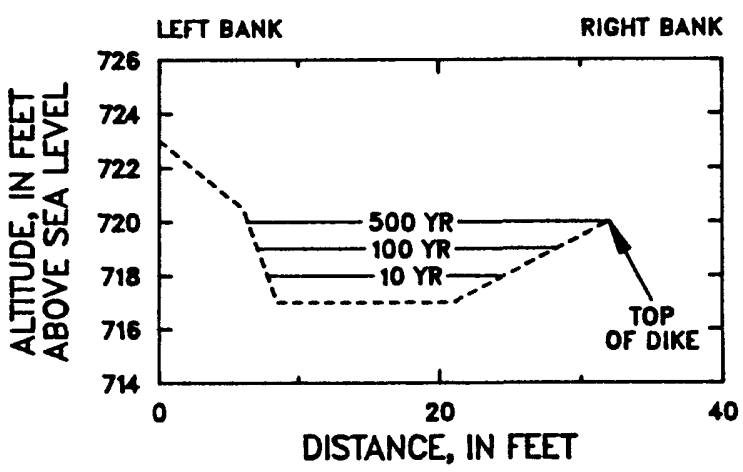

SECTION G

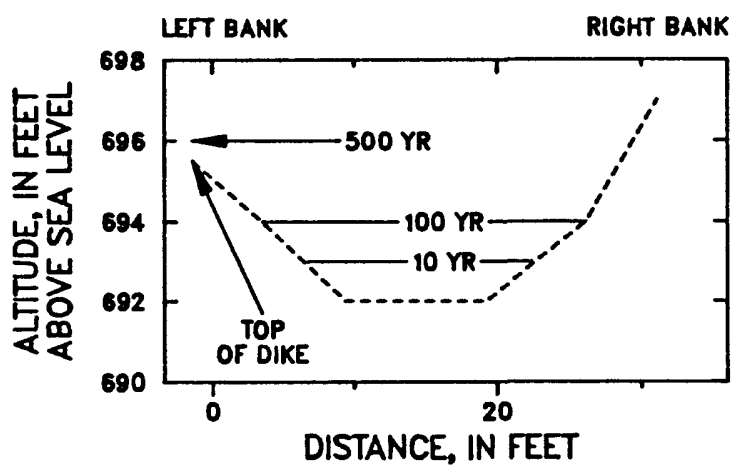

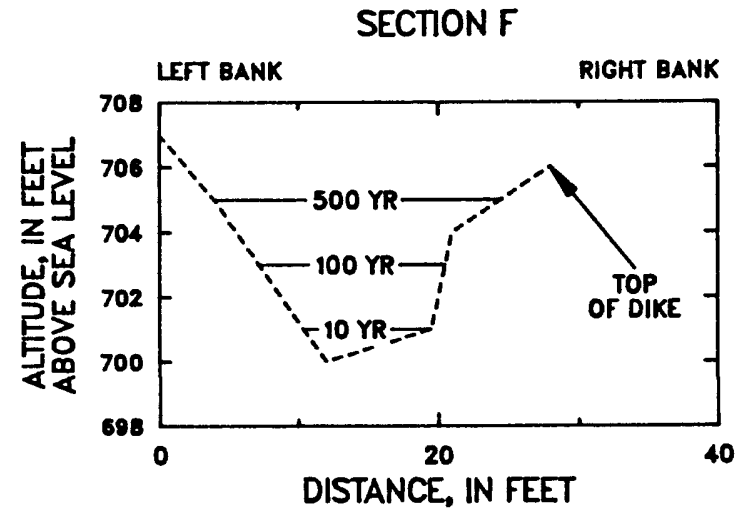

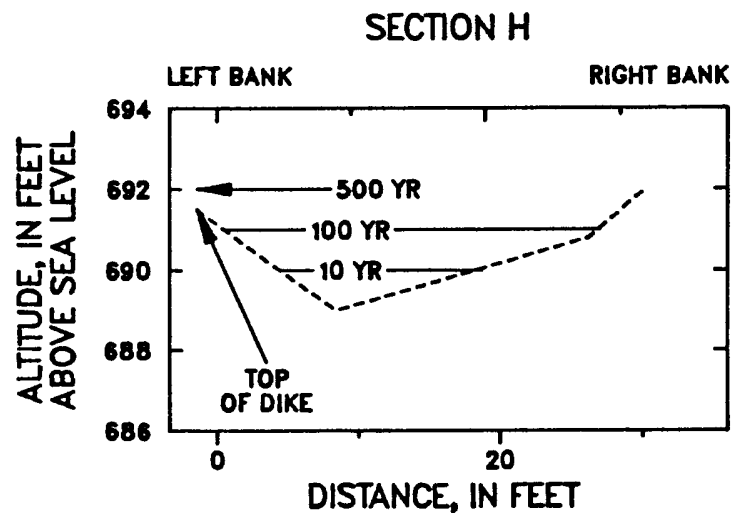

\begin{tabular}{|c|c|c|c|c|c|c|c|c|}
\hline \multirow[b]{2}{*}{$\begin{array}{l}\text { Recurrence } \\
\text { interval } \\
\text { of peak } \\
\text { discharge } \\
\text { (years) }\end{array}$} & \multicolumn{2}{|c|}{ section $E$} & \multicolumn{2}{|c|}{ section f } & \multicolumn{2}{|c|}{ section $G$} & \multicolumn{2}{|c|}{ section $H$} \\
\hline & $\begin{array}{l}\text { Hean } \\
\text { velocity } \\
\text { (feet } \\
\text { per } \\
\text { second) }\end{array}$ & $\begin{array}{l}\text { Haximum } \\
\text { depth } \\
\text { (feet) }\end{array}$ & $\begin{array}{l}\text { Hean } \\
\text { velocity } \\
\text { (feet } \\
\text { per } \\
\text { second) }\end{array}$ & $\begin{array}{c}\text { Maxinum } \\
\text { depth } \\
\text { (feet) }\end{array}$ & $\begin{array}{l}\text { Mean } \\
\text { velocity } \\
\text { (feet } \\
\text { per } \\
\text { second) }\end{array}$ & $\begin{array}{l}\text { Haximum } \\
\text { depth } \\
\text { (feet) }\end{array}$ & $\begin{array}{l}\text { Hean } \\
\text { velocity } \\
\text { (feet } \\
\text { per } \\
\text { second) }\end{array}$ & $\begin{array}{c}\text { Haximum } \\
\text { depth } \\
\text { (feet) }\end{array}$ \\
\hline 10 & 4 & 1 & 5 & 1 & 5 & 1 & 5 & 1 \\
\hline 25 & 5 & 1 & 7 & 2 & 6 & 1 & 5 & 1 \\
\hline 50 & 6 & 2 & 7 & 2 & 6 & 2 & 6 & 2 \\
\hline 100 & 7 & 2 & 8 & 3 & 7 & 2 & 7 & 2 \\
\hline $\begin{array}{c}500 \\
\text { extrene }\end{array}$ & $\begin{array}{r}9 \\
>9\end{array}$ & ${ }^{3}$ & $\begin{array}{r}10 \\
>10\end{array}$ & $>5^{5}$ & $\begin{array}{r}9 \\
>9\end{array}$ & $\begin{array}{l}>3 \\
>3\end{array}$ & $\begin{array}{l}>7 \\
>7\end{array}$ & $\begin{array}{l}>2 \\
>2\end{array}$ \\
\hline
\end{tabular}

"Exceeds channel capacity.

FIGURE 6.-.Floodflow characteristics, North Katherine Landing Wash. 

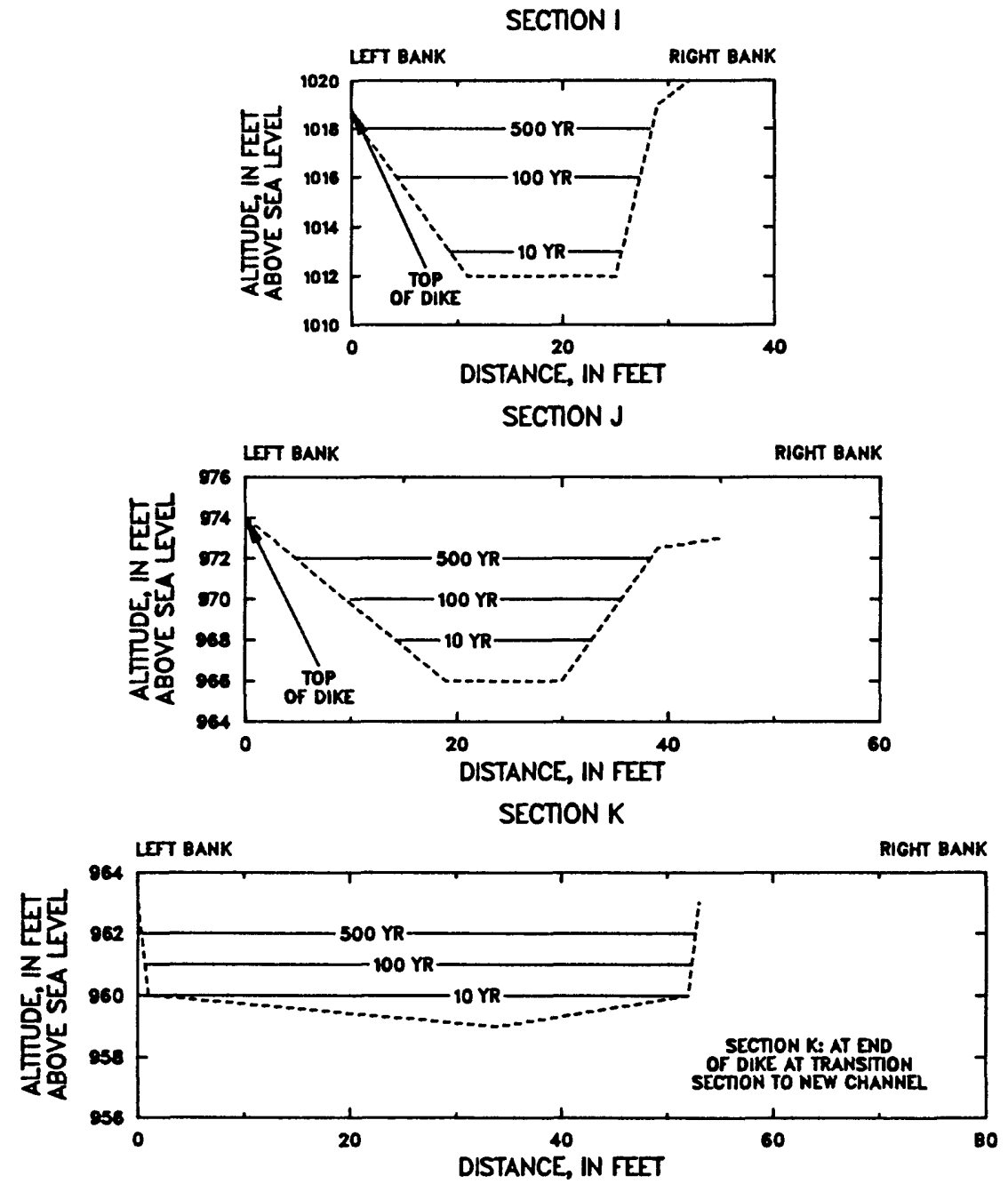

\begin{tabular}{|c|c|c|c|c|c|c|}
\hline \multirow[b]{2}{*}{$\begin{array}{c}\text { Recurrence } \\
\text { interval } \\
\text { of peak } \\
\text { discharge } \\
\text { (years) }\end{array}$} & \multicolumn{2}{|c|}{ section I } & \multicolumn{2}{|c|}{ section $J$} & \multicolumn{2}{|c|}{ section $k$} \\
\hline & $\begin{array}{c}\text { Mean } \\
\text { velocity } \\
\text { (feet } \\
\text { per } \\
\text { second) }\end{array}$ & $\begin{array}{c}\text { Haximum } \\
\text { depth } \\
\text { (feet) }\end{array}$ & $\begin{array}{c}\text { Mean } \\
\text { velocity } \\
\text { (feet } \\
\text { per } \\
\text { second) }\end{array}$ & $\begin{array}{l}\text { Maximum } \\
\text { depth } \\
\text { (feet) }\end{array}$ & $\begin{array}{c}\text { Mean } \\
\text { velocity } \\
\text { (feet } \\
\text { per } \\
\text { second) }\end{array}$ & $\begin{array}{c}\text { Maximum } \\
\text { depth } \\
\text { (feet) }\end{array}$ \\
\hline 10 & 6 & 1 & 6 & 2 & 5 & 1 \\
\hline 25 & 8 & 2 & 8 & 2 & 6 & 2 \\
\hline 50 & 9 & 3 & 8 & 3 & 7 & 2 \\
\hline 100 & 10 & 4 & 9 & 4 & 7 & 3 \\
\hline $\begin{array}{c}500 \\
\text { extreme }\end{array}$ & $\begin{array}{r}12 \\
>12\end{array}$ & $>6^{6}$ & $\begin{array}{r}11 \\
>11\end{array}$ & ${ }^{6}$ & $\begin{array}{r}10 \\
>10\end{array}$ & $>4$ \\
\hline
\end{tabular}

Exceeds channel capecity.

FIGURE 7.--Floodflow characteristics, South Telephone Cove Wash. 
Potential debris hazards are related to the quantity and character of debris available for mobilization by the flood flows. Damage can be caused by erosion of valuable land areas, debris deposition, abrasion and impact forces of moving debris, and diversion and modification of floodflows as described above.

Large quantities of inorganic debris, which would be mobilized by floodflows, are present in the major drainages of the Katherine Landing and Telephone Cove sites. Floodflows are water-dominated mixtures of water and sediment. Magnitudes of peak discharges (table 1) are estimates of the water-dominated flow mixture, in cubic feet per second. All washes in the study site contain abundant quantities of sand, gravel, and cobbles that would be mobilized during moderate to intense flooding. The potential hazard for severe impact by large-size debris (boulders) is negligible. The predominantly sand and gravel size of the debris in the channels suggests that most debris-related flood damage would consist of erosion in the channels and deposition near the delta.

\section{Katherine Landing}

Bank and channe1-bed configurations of Katherine Landing have been significantly altered by recreation-area development. As of 1979, the following are the significant conclusions:

1. In predevelopment time, the alluvial area of Katherine Landing was fed by several washes having drainage areas of slightly more than 2.76 square miles (combined total for sites 4, 5, and 6, table 1 and figure 3 ). The channels were probably not significantly incised but instead shifted laterally within the $1 / 4-m i l e-w i d e$ area.

2. A northwest-trending earth-fill dike at site 6 (table 1 , figure 3 ) has diverted flow to South Telephone Cove Wash that in predevelopment time entered the Katherine Landing area. The dike is about 6-8 feet high, and appears well consolidated and stable. (A detailed appraisal of the structural integrity of the dike is beyond the scope of this investigation.)

3. A gravel borrow pit upstream from site 2 (table 1 and figure 3) drastically reduces or completely stores inflow draining to North Katherine Landing Wash. An earth dike, a spillway, and a small culvert regulate outflow from the borrow pit. The earth dike (dam) is about 15 feet high, and at spillway elevation the impoundment can store about 32 acre-feet of water.

4. Drainage south of the access road and residual flow (if any) from the borrow pit have been routed to Lake Mohave by way of South Katherine Landing Wash (sites 2, 3, 4, table 1 and figure 3). This was accomplished by diking the flow to the consolidated rock area that borders the Katherine Landing alluvial area on the south and by using spur dikes that are designed to divert unchanneled flow between the access road and the wash. All remaining water north of the access road at Katherine Landing drains naturally to North Katherine Landing Wash. 
The top of the dike on South Katherine Landing Wash is generally 3 to 5 feet higher than the protected areas. For short reaches the channel has been cut through bedrock. Gabions, ranging in height from 2 to 4 feet, are not continuous but provide additional stability to the dike. The bottom of the channel, or thalweg, is generally 0 to 2 feet lower than the adjacent protected areas. The spur dikes are about the same dimensions as the channel dike.

5. On North Katherine Landing Wash the top of the dikes are usually only 0 to 2 feet higher than the protected areas, and the thalweg ranges from about 3 to 5 feet lower than the protected areas.

\section{Telephone Cove}

Telephone Cove, as considered for this study, consists of two main use areas, South and North Telephone Cove Washes (sites 7 and 8 in table 1 and figure 3 ), that have no man-made developments. Use is mainly by recreational vehicles near the shoreline of Lake Mohave.

\section{DISCUSSION OF STUDY RESULTS}

On the basis of 1979 channel conditions and locations of dikes, flood elevations, velocities, and depths were computed for minimum-capacity cross sections in South Katherine Landing Wash, North Katherine Landing Wash, and in the diked wash that diverts flow to South Telephone Cove Wash. Maximum velocities may be up to about 50 percent greater than the mean velocities tabulated in figures 5-7. Maximum depth is the difference in elevation between the water surface and the lowest ground elevation at the section in question. Pileup due to obstructions and channel curvature (outside curve of bends) may increase flow depths. The increase of flow depth is related to the degree of channel curvature; it may be less than 1 foot at a velocity of 5 feet per second but almost 2 feet at a velocity of 10 feet per second. In addition, because the discharges for the floods of different recurrence interval have standard errors of estimate of 80-105 percent, the peak-flow depths have errors of estimate that may be as much as plus or minus 2 feet for the 100-year and 500-year floods. Flow depths consequently may be overestimated or underestimated.

Conclusions as to potential hazards may be summarized as follows:

1. The present (1979) channel along South Katherine Landing Wash will convey a 100-year flood with or without contribution of flow from the borrow pit drainage area. Estimated flow capacity of the wash at minimum conveyance sections ranges from 800 to $1,500 \mathrm{ft}^{3} / \mathrm{s}$. The estimated 100-year peak discharge of the wash at its mouth (table 1 , site 4) is about $450 \mathrm{ft}^{3} / \mathrm{s}$ without flow from the borrow pit and its tributaries, and about $660 \mathrm{ft}^{3} / \mathrm{s}$ with flow from the pit and its tributaries. Comparable values for the estimated 500-year peak discharge are about 1,000 and $1,500 \mathrm{ft}^{3} / \mathrm{s}$, respectively, both of which exceed the capacity of the channel at several locations. 
The dikes appear to be generally well-compacted, have established vegetation, are mostly 20 feet or more wide at their bases, and give an overall impression of stability. (A detailed appraisal of the structural integrity of the dikes is beyond the scope of this investigation.) If channel capacity is exceeded, partial erosion of the dike rather than total dike failure is considered more likely. Overflow or flow from partial dike failure probably would only seriously affect the reach between the employee residences (figure 2) and the mouth of the wash. In that reach are located a large parking lot, a motel, the access road, and additional vehicle parking near the mouth of the wash. For up to a 500-year flood, the most critical hazard situation may well be near the mouth in the parking and roadway areas.

As part of the study, the storage capacity of the borrow pit and the effect of the pit on flood inflow (site 2, table 1) were investigated. An earthen dam with a concrete spillway is in place. A corrugated metal-pipe culvert, 3 feet in diameter, provides some storage release before water reaches the spillway elevation. The storage capacity of the pit at spillway elevation is almost 32 acre-feet. A storage volume of 32 acre-feet is equivalent to about 0.85 inch of water and sediment uniformly distributed over a drainage area of 0.70 square mile (table 1 ). By the use of a common technique in watershed hydrology, the volume of a floodflow can be estimated by using the drainage area, the peak instantaneous flow, and the time of concentration (Chow, 1964, p. 21-42, 21-43). By rearranging terms, the applicable equation becomes:

$$
Q_{v o l}=\frac{Q_{\text {peak }}\left(\sqrt{T_{c}}+0.6 T_{c}\right)}{484 \mathrm{~A}},
$$

where $Q_{v o l}=$ flow volume associated with $Q_{\text {peak, }}$ in inches of depth uniformly distributed over the drainage area.

$$
\begin{aligned}
Q_{\text {peak }} & =\text { flow peak, in cubic feet per second; } \\
T_{C} & =\text { time of concentration for the drainage area, in hours; and } \\
A & =\text { drainage area, in square miles. }
\end{aligned}
$$

One method of estimating $T_{C}$ is provided by Kirpich (1940):

$$
T_{c}=0.00013 \frac{L^{0.77}}{S^{0.385}},
$$

where $L=$ drainage area length, in feet, along the longest stream course, and

$S=$ slope, ratio of total fall to $L$ along the longest stream course. 
The drainage area length $(L)$ is 7,400 feet and the slope $(S)$ is 0.099 . Evaluating equation (2), $T_{c}=0.3$ hour. Substituting in equation (1), $Q_{v o l}=1.05$ inches depth over the entire drainage area. This volume, associated with the 100-year peak flow of $490 \mathrm{ft}^{3} / \mathrm{s}$, is somewhat greater than the computed storage capacity of the borrow pit $(0.85$ inch, depth over the entire drainage area). Given the uncertainties in the volume and peak estimations, the 100-year peak flow will probably fill the borrow pit and spill a small amount either through the culvert or both through the culvert and over the spillway. A flood larger than the 100-year event will almost certainly cause spill. A very serious concern, not within the scope of this study, is the effect of (1) a reduction in pit volume due to sediment accumulation over time or (2) the presence of a significant volume of stored water in the pit at the time of a severe flood.

2. The 100-year peak discharge of North Katherine Wash would be contained within its banks. The channel capacity at cross sections with minimum conveyance ranges from about 320 to $700 \mathrm{ft}^{3} / \mathrm{s}$. The estimated 100-year peak discharge for the wash is $260 \mathrm{ft}^{3} / \mathrm{s}$. The estimated 500-year flood of $610 \mathrm{ft}^{3} / \mathrm{s}$ exceeds the capacity of the channel at some locations. Damage caused by overflows could be only minor, but if the flood breaches the diked channel (most likely at the mobile home areas), and a new channel is established, damage could be significant.

3. The diked channel that was designed to divert flow to South Telephone Cove Wash (site 6 and upstream) has a channel capacity of $1,700-3,000 \mathrm{ft}^{3} / \mathrm{s}$ at sections with minimum conveyance. The 100-year and 500-year peak discharges are estimated at 660 and $1,500 \mathrm{ft}^{3} / \mathrm{s}$, respectively.

4. Without protective works, areas on the flood plain and delta at both North and South Telephone Cove are exposed to potentially extremely hazardous flooding conditions because of the relatively large estimated flows that can be expected (sites 7 and 8 , table 1) and the possibility of shifts in the location of the channel during flow periods.

5. The extreme flood could be extremely hazardous to life and property, expecially in the vicinity of the washes at Katherine Landing. The dikes at both North and South Katherine Landing washes would be overtopped and breached. To complicate matters, the dike that now diverts flow to South Telephone Cove Wash may fail. The additional water would then flow through Katherine Landing. 
6. During and immediately after intense local rains, sheet flooding at Katherine Landing may cause some inconventence and damage by erosion and sediment deposition.

7. The conclusions from this study are contingent largely on the continued maintenance and integrity of the channels, dikes, and the borrow-pit dam. Channel obstructions may reduce flow capacities and contribute to dike failure. Conceivably, sudden failure of the borrow pit dam when the volume of stored water is large could produce peak discharges well in excess of the 100-year and 500-year floods and breach the diking system downstream. A detailed appraisal of the integrity and safety of the dam and the entire dike system was not within the scope of this study. A continuing program of dike maintenance and dam inspection seems prudent. In addition, periodic removal of debris from the borrow pit would allow for proper functioning during a major flood event. 


\section{REFERENCES CITED}

Chow, V. T., 1962, Hydrologic determination of waterway areas for the design of drainage structures in sull drainage basins: University of Illinois Engineering Experimental Station Bulletin 462 .

--1964, Handbook of applied hydrology: New York, McGraw-Hi11, $1453 \mathrm{p}$.

Crippen, J. R., and Bue, C. D., 1977, Maximum floodflows in the conterminous United States: U.S. Geological Survey Water-Supply Paper 1887, 52 p.

Kirpich, Z. P., 1940, Time of concentration of small agricultural watersheds: Civil Engineering, v. 10, no. 6, p. 362.

Potter, W. D., 1961, Peak rates of runoff from small watersheds: U.S. Bureau of Public Roads, Hydraulic Design Report 2.

Roeske, R. J., 1978, Methods for estimating the magnitude and f requency of floods in Arizona: Arizona Department of Transportation Final Report ADOT-RS-15 (121), 82 p.

Waananen, A. 0., and Crippen, J. R., 1977, Magnitude and frequency of floods in California: U.S. Geological Survey WaterResources Investigations Report 77-21, 96 p. 